\title{
Self-Conception of The Vagrants in Jakarta
}

\author{
Syaiful Rohim ${ }^{\mathbf{\varpi}}$ \\ ${ }^{1}$ Universitas Muhammadiyah Prof.Dr.Hamka \\ Permalink/DOI: http://dx.doi.org/10.15294/komunitas.v7i1.3595 \\ Received : Feb 2015; Accepted: March 2015; Published: March 2015
}

\begin{abstract}
This research aims to identify the self construction and communicating acts amongst the vagrants while doing their daily activities as vagrant in Jakarta. The method used for this research was a qualitative method with phenomenologist paradigm which aims to understand human behaviors from an experimental subject perspective. The observation used an in-depth interview technique as well as participant's observation technique. This study is known as an emic study to further identify self construction based on ideographic analysis which aims to give a brief description regarding self communicating acts among vagrants. Result from this analysis will not be quantified nor generalized with other cases. Result shows that vagrants, especially those who have the same profession, tend to share the area of work in order to avoid conflicts among them. Description from the subject in establishing communication with other vagrants is done by sharing area of expertise from himself and other vagrants. Results also showed that almost all the subjects tend to close their "darker" side from others who don't know that they are vagrants by impression management. These people came into existence not only because of a poor culture which shows nomadic type of living habit, but it's also because of the structure and vast majority which sees them with a negative stigma for every type of occupation they choose including a forced action because they were left without any choices other than being a vagrant.
\end{abstract}

\begin{abstract}
Abstrak
Penelitian ini bertujuan untuk mengidentifikasi pembentukan konsep diri tunawisma saat mereka melakukan kegiatan sehari-hari mereka sebagai tunawisma di pusat kota Jakarta. Metode yang digunakan untuk penelitian ini adalah metode kualitatif dengan paradigma fenomenologi yang bertujuan untuk memahami perilaku manusia dari perspektif eksperimental. Hasil menunjukkan bahwa tunawisma, terutama mereka yang memiliki profesi yang sama, cenderung berbagi wilayah kerja untuk menghindari konflik di antara mereka. Tunawisma juga berbagi bidang keahlian satu sama lain. Hasil menunjukkan bahwa mereka menutupi sisi "gelap" mereka dari orang lain yang tidak tahu bahwa mereka adalah gelandangan melalui manajemen kesan. Orang-orang ini muncul bukan hanya karena budaya miskin yang menyebabkan mereka hidup nomaden, tetapi juga karena struktur dan mayoritas yang melihat mereka dengan stigma negatif untuk setiap jenis pekerjaan mereka pilih. Mereka juga menjadi gelandakan karena terpaksa, tidak ada pilihan lain.
\end{abstract}

Keywords: phenomenology; vagrant; qualitative

How to Cite: Rohim, S. 2015. Self-Conception of The Vagrants in Jakarta. Jurnal Komunitas, 7(1):53-58. doi:http://dx.doi.org/10.15294/komunitas.v7i1.3595

(C) 2014 Semarang State University. All rights reserved

$凶$ Corresponding author :
Address: J1. Limau 2 Kebayoran baru Jakarta Selatan




\section{INTRODUCTION}

The emergence of the vagrants in urban environment is a symptom of social culture which relatively catches the attention of various parties, no exception for researchers. In general, the rise of the vagrant appears simultaneously with the development of the urban environment, in line with the needs of workers, a cheap labor in supporting the process of growth and development of the city. The occurrence of the vagrant generally come from rural communities who migrate to the city to seek their fortunes, to seek more decent jobs and receive enough commission to change his life in the countryside.

Jakarta as the adequate and sufficient seat of government, economy and other social amenities can motivate and inspire someone to come and try to snitch his/her fate in hope of getting a decent livelihood rather than in the village. As recognized by Iswandi in the interview done by Trans 7 in the show "Gerobakku Harapanku" that he came to Jakarta to try to seek his fortune in hope that he could get a job, decent and better income, but having arrived in Jakarta he can only live as a vagrant with his wife and one daughter draping their lives by going round as a street scavenger, picking up garbage on the streets and housings.

Based on the exposure and the description above, a research on the life of vagrants is interesting to do because it is not only to uncover subjective reality of the one who enters the world of vagrants but also to reveal the negative image and cultural construction that is considered deviant and treatment experienced by the vagrants in their activities, in a certain area and limitation that makes them have a way, value and tradition of a culture that is different from the others. Vagrants re-interpret their behavior from normal people's objectification to be able to live together with them. Vagrants expect the public to give them legitimacy of their attitude, and do not want the people to thwart their struggles and existence.

Theoritical concepts of symbolic interactions can guide researchers to depict

1 "Gerobakku Harapanku” Trans 7, Jum'at 12 Februari 2010 from the reality description and the portrait of vagrants phenomenon in Jakarta. Social life in the view of the symbolic interaction means a human interaction by using a symbol that is always used by people to communicate and interact to each other. In these interactions also occur efforts to define and interpret to each other between one action with the other in negotiating the exchanged meanings. Self or the self conception in the view of Mead (in Mulyana: 2004: 73) is a process that comes from the individual's social interaction with other people, or the other definition, the self is also a "social object" which we share to other people in an interaction (Soeprapto: 2002: 204).

Thus, the self conception of every individual is largely determined by how others see/assess themselves when interacting. Cooley (in Mulyana, 2002: 74) said that the self conception of the individual is significantly determined by what he/she thinks about other people's thoughts about him/ her. Therefore, if this theory (symbolic interaction) as one perspective (the theory) for 'observing 'the reality of vagrants' communication, it will be very precise and exciting. Moreover, the theory of symbolic interaction has become one of the perspectives in communication studies (Littlejohn, 1996: 159).

The social construction of deviant behavior/devians play an important role in the process of labelling occurred in the community. This process not only involves a labelling of devians' criminal behavior that do not conform to social norms, but also reflects stereotyping and stigmatization of deviant behavior. Vagrant is a social group that is regarded as a person who is considered to be deviant. Even often, feeling suspicious as well as contemptible, trifling, and sordid identical to taking possession of another person, causing vileness, cunning and causing crime. A label or a nickname will always be carried as long as they choose to live as homeless people, who certainly will organize, act, and be alleged to behave according to the self image gained from the social groups who are not from the community. At the same time it will also set up a 
system of communication and interaction with the community outside the homeless community. As Mulyana (2004; 173) said that the insistent definition of others will replace their self-image even though it was originally at odds with their wishes. The impact of labelling is more powerful when it is also disseminated by the press especially if the labelled ones are commoners.

In an effort to present themselves, sometimes the actor is facing various problems about his/her "self" among for example about self-image he wants other people to see, with the actual identity, especially the self-image has a stigma (disabled), whether it is physical or social stigma. In the case of physical stigma, the actors assume that the audiences know that the actors are physically different to them, whereas in the case of social stigma, the audiences do not know and see it. If seen from one of the studies about self presentation then this question would be more appropriate to make dramaturgis theory as part of the theoretical review. Dramaturgis approach Goffman specifically centers on the view that when humans interact with each other, they would like to manage the impression that they are expected to grow in others toward them. To that end, each person performs a show for others (Mulyana, 2001: 107), so this life according to Goffman is like an acting stage. By following this theatrical analogy, Goffman talks about the front stage and the back stage (Ritzer, 2004: 298).

\section{METHOD}

This research used qualitative research methods with the phenomenological research tradition. In terms of Lindlof (1995: 27), it is called as the interpretive paradigm to refer to communication research with qualitative method which performed the tradition of Phenomenology, symbolic interaction, etnometodologi, ethnography and cultural studies. Creswell (1998: 14) says that the qualitative research is a research whose background, location and time are natural.
This paradigm also allows a qualitative interpretation on the research data that has been retrieved. In addition, this research will provide a great opportunity to establish the alternative interpretations. Mulyana (2004) mentions this qualitative research as a subjective perspective.

As the general phenomenological tradition explains the meaning of life experience of a number of people about a conception or symptoms (Creswel, 1998: 51), this research will also attempt to describe the life experience of the subject (vagrants), using biographical studies to trace the life history of the vagrants. One of the characters of phenomenological qualitative research is conducting an observation and interaction with the subjects of research to try to understand their language and interpretation of the world. Things like this are also emphasized by Creswell (1998: 14) that qualitative research is a research whose background, location and time are natural. This paradigm also allows a qualitative interpretation on the research data that has been retrieved. In addition, this research will provide a great opportunity to establish the alternative interpretations (Littlejohn, 1996: 16).

\section{RESULTS AND DISCUSSION}

\section{Vagrants' Self Image}

The perception or assumption of the research subject about their physical, psychic and social conditions which indicate them as the vagrants that have negative self conception will be described in detail. An explanation of the subject's view toward all physical things is meant as a subjective perception of communication behavior presented based on thier views about physical appearance, attributes used in conducting interaction and doing their professions. In a subtle behavioral communication initiated by the subject can be seen when they are wearing their attributes and their daily behavior. The results of the study at least found some activities carried out by the subject in this study that show the physical characteristics that characterize their identity such as a dirty and dishevelled appearance, using wagon 
as a place to live, means of transportation and working, disordered eating, and health problems.

Related to the behavior or psychological perception of the vagrants, some of the behaviors shown are withdrawal, leaving the religious devotion, feeling inadequate, lazy and manipulation of goods (lying) as for the social tendency is by avoiding social contact, violation of the norms and ethics of society.

In general, a positive self conception is seen in some of the psychological behaviors shown with optimistic attitude, confidence and always have positive attitude toward everything even failures. Failures are not looked upon as death, but rather making it as a discovery and a valuable lesson to step forward. People with a positive self conception will be able to appreciate themselves and to see the positive things that can be done for the sake of their success in the future. Subject informant in the category of the homeless that has positive physical self conception generally expressed the idea energetically and showed a cheerful face. Although he seemed to be physically tired and exhausted due to a long day of walking and vagrancy looking for second-handed goods and pulling his wagon.

\section{Vagrants' Typology}

Based on a wide range of views and opinions of the research subjects about various things are both regarding to him and about other people and the environment. From my observation about the phenomenon of vagrant families' daily activities, so the researchers can make some typologies toward the research subjects namely: optimistic vagrants, pessimistic vagrants, and conditional vagrants.

On the typology of pessimistic group, the vagrants with this label and typology show more attitudes that are not passionate to live their lives and to select the profession as an alternative job. They tend to be moody, inferior, fantasizing, and choosing to work as a beggar. The research subjects like this usually have a negative physical, social and psychological perception, and also live his life pessimistically. Even inspite of their pos- ture and their young age, they manifested themselves as slackers. In religious term, the research subjects in this typology do not look like to do praying activities.

The term of optimism for this second typology is judged appropriate given the subject of the research included showing an energetic attitude and demonstrating a sense of optimism and it is very visible on their enthusiasm to transform their lives, especially in term of earthly business. In the discussion, they still show the good quality contents of the speech, systematic way and delivered enthusiastically whereas conditional vagrants' typology has several traits that arise when interacting with the outside world. In the categories they consider their jobs as a scavenger and nomad because it is to increase mobility and expand of the coverage of the areas that can be considered to have a lot of opportunities to pick up good items.

In addition, the topology of the subjects that have this character has the habit to respond and be perceptive about the opportunities to get a lot of results and they also have no intention to try to find additional money by being a beggar. However, they are very responsive to the environment outside especially if there is information on the activities of the authorities. They are always prepared to immediately avoid them so they will not be arrested.

\section{Motivation and Career Option of the Research Subjects}

Based on the research results through indepth interviews and observations, the depiction of the motive or the reason of the subjects in this study is obtained. They are: 1) about poverty (economic term); one of the motives described in the results of this research is that poverty or unability in economic term became the motivation for someone to become a vagrant, 2) about family (family matter), another issue encouraging and motivating a vagrant in this research subject so that the vagrants are getting rampant in Jakarta is not only concerned about poverty and economic problems, but also social and cultural problems. 
A typology of the vagrants who have a profession as a beggar is generally performed by a group of seasonal vagrants who come to Jakarta during the fasting month and Idul fitri holiday. However, nearly half of the research subjects acknowledge that they actually become a beggar although packed with a wagon or cart as the attribute or accessories to provoke people to feel merciful, especially for car drivers and motorbike riders.

\section{The Impression Management of Va- grants based on Communication "Set- ting"}

In the writing of this study, researcher divided subjects' acts as a communication behavior that based on the impression management based on communication setting by the way of choosing the time, area and work divison as a social setting and communication setting. 1) By doing activity based on the time setting, based on the results of research, observation and in-depth interviews conducted with all the subjects in this study, the information and representation regarding the conception and consideration about time as a consideration when the subject are working to pick up second-hand goods were obtained. The subject in this study realized very well that knowledge of planning time will not only have an impact on the results obtained, but also closely related and intertwined with the interaction and communication with others. 2) Working based on area selection; the daily work of the vagrants as the subjects in general is a scavenger, i.e. collecting used goods for sale or using them. For them, there is not any main location as a target because second-handed items can be obtained anywhere. Based on the interview with the research subjects, places that are believed to have more resources and quality than other locations were obtained. A wide variety of their working areas that researcher had found that is frequent and often visited by the subjects that use carts in their activity of picking up the second-handed items are streets, market area, residential area, social facilities such as hospitals, schools, etc, and public garbage containers. Places that are believed to have excess resources will in turn be controlled by particular vagrant so that there is a guarantee for the income continuity for him/her in the future. One of the tactics put into practice was to give a sign, i.e. with a wagon/cart parked near the garbage container.

\section{Vagrants' "Self" Management toward Communication Partner}

Interactive communication and self presentation performed by the subjects in this research were at least done with several communication participants that each of which gave information about the treatment and definitely different ways of communication. In general, they interact and communicate with some groups such as with fellow scavengers, stall owners, and the authorities (Civil Service Police Unit "Satpol PP"). The relation with the fellow scavengers in the category of front stage, besides sharing experience, they also help each other. The scavengers in the category of back stage consider that the other scavengers are their competitors in collecting second-handed items.

In the relation with the stall owners categorized as front stage, the subjects consider the stall owners as a place to distribute and sell the items obtained by the vagrants so it makes the stall owners as a respected and feared person. While some of the behavior indicated by the subjects when having an interaction with the stall owners as back stage in this study are indicated by some communication behaviour i.e. lying habit such as making the items wet before weighing them, mixing the items and telling that they are sick so they will not pay the debt.

One of the efforts often performed by the vagrants of front stage behavior in this research is parking the cart near the traffic light or by the roadside; this way was done as a means to trick people that they are beggars. Beggars' behavior conducted by some of the subjects in this study by sitting on the edge of the sidewalk together with their children and wives is the way to avoid the raid by Civil Service Police Unit (Satpol PP). 


\section{CONCLUSION}

Self image of the subjects in doing communicative relation with the communication partner is done by dividing their own area: the self image for other people and the self image for themselves. The reason why the subjects work as a scavenger is caused by some factors that are all related and interconnected one another. The results, from that reasons, is categorized based on orientation or cause motive (includes: bankrupt business and friends' persuasion) and motive which includes economic and family factors.

The self conception of a person especially the subjects in this study is the social product formed through a process of internalization and organizing psychological experiences. These psychological experiences are the result of individual exploration toward the physical environment and his/ her reflection with the surroundings. The selection of the vagrants' careers done by being scavengers and beggars are based on rational choice and the consideration of the subjects as well as the effectiveness of their goals to meet their daily needs. They perform impression management with a variety of partners, such as communication with fellow scavengers, the stall owners, and Civil Service Police Unit (Satpol PP).

Some planning strategy on self management of the subjects in this research is done by using a social setting as communication setting, i.e. by doing their working activities based on time selection and area selection.

\section{REFERENCES}

Berger, P.L \& Thomas L. 1966. The Sosial Construction of Reality : A Treatise in the Sociology of Knowledge. New York: Anchor Books.

Berger, P.L \& Thomas L. 1990. Tafsir Sosial atas Kenyataan. Alih Bahasa Frans M Parera. Jakarta: $\mathrm{LP}_{3} \mathrm{ES}$.

Cresswell, W.J. 1998. Qualitative Inquiry and Research Design Choosing Among Five Traditions. California: Sage Publications, Inc.

Lindlof, T.R., 1995. Qualitative Communication Research Methods, California USA: Sage Publication

Littlejohn, S.W. 2002. Theories of Human Communication. USA: Wadsworth Publising Company

Mulyana, D. 2001. Metodologi Penelitian Kualitatif. Paradigma Baru Ilmu Komunikasi dan Ilmu Sosial Lainnya. Bandung: Rosda Karya.

Mulyana, D. 2004. Ilmu Komunikasi Suatu Pengantar. Bandung: Remaja Rosdakarya

Ritzer, G. \& Douglas J.G. 2004. Teori Sosiologi Modern. terj. Alimandan. Jakarta: Kencana

Suprapto, T. \& Fahrinoor. 2004. Komunikasi Penyuluhan.Yogyakarta: Arti Bumi Intaran 